\title{
The year that is not yet over - Paidéia: Management Report - 2020
}

\section{O ano que ainda não terminou - Paidéia: Relatório de Gestão - 2020}

\section{El año que aún no ha terminado - Paidéia: Informe de Administración - 2020}

\author{
Manoel Antônio dos Santos ${ }^{1}$ \\ Eduardo Name Risk ${ }^{2}$ (iD
}

This Report has been published in 2021, an important year in the history of our journal because Paidéia celebrated its 30th anniversary. On August 19, 2021, we had a commemorative event organized by the Paidéia's Editorial Board members (Psychology Graduate Program - Programa de Pós-Graduação em Psicologia USP-RP, 2021). Long life to Paidéia.

This Management Report compiles data regarding the processing of manuscripts submitted to Paidéia (Ribeirão Preto) in 2020. As we could not fail to mention, 2020 was also a year marked by the global health crisis caused by the COVID-19 pandemic (Oliveira, Oliveira-Cardoso, Silva, \& Santos, 2020). We mentioned that it is as if the year 2020 "did not really ended" because it was abruptly interrupted by the emergence of an unusual and critical event that haunted the entire world and took the lives of millions of people. Grieving families were prevented from saying goodbye to their loved ones, which impeded the mourning process (Oliveira-Cardoso et al., 2020). Dreams, plans, and projects were suspended and, above all, habits and ways of living life were drastically shut down. This is why we argue that the year is not over yet. Its aftermath, open wounds, interrupted mourning, and postponed embraces have set the marks of a dark period in human history (Santos, Oliveira, \& Oliveira-Cardoso, 2020).

The spread of COVID-19 required sanitary measures to safeguard lives (Oliveira et al., 2020a). This major event brought significant challenges to humanity that impacted all areas of life (Ferreira, 2021; Oliveira et al., 2020b, 2021). Social distancing measures imposed restrictions that had to be handled with competence and sensitivity by the journal's Editorial Board. We are grateful to all Paidéia's Editorial Board members and administrative staff, who made additional efforts to maintain the journal's routine. Counting on understanding, competence and commitment of all members, authors and colloborators was possible to keep the pattern and periodicity intact.

\footnotetext{
${ }^{1}$ Universidade de São Paulo, Ribeirão Preto-SP, Brasil

${ }^{2}$ Universidade Federal de São Carlos, São Carlos-SP, Brasil
}

Correspondence address: Manoel Antônio dos Santos. Universidade de São Paulo. Faculdade de Filosofia, Ciências e Letras de Ribeirão Preto. Departamento de Psicologia. Av. Bandeirantes, 3900, Ribeirão Preto-SP, Brasil, CEP 14.040-901. E-mail: masantos@ffclrp.usp.br
Scientific editing is a fundamental area of knowledge production whose findings are disseminated mainly in the form of papers, which enjoy the peculiarity of having been assessed by ad hoc consultants, which guarantees a priori their minimum "quality". It is a complex process that does not involve only the direct relationship between author/editor/ reviewer, considering that these are crowded in educational/ research institutions, which, in turn, are under the satellite of research promotion agencies and the science and technology policy of the country. Thus, publishing a scientific journal implies the management of relations between the academic and political-scientific bodies that guide the guidelines of a specific area (Risk, 2010).

The growing concern with the quality of the editorial process is linked to decision-making for different scientific issues with significant impact on society, public policies and professional practices (Carvalho, Pianowski, $\&$ Santos, 2019). In this Management Report, we present indicators that give visibility to the editorial management of Paidéia for the year 2020. With the publication of this document, we preserve the tradition of presenting to the scientific community a balance of what the journal has produced in the previous year. It makes explicit the modus operandi of the processing of the manuscripts in the period. The dissemination of scientific production is backed by a rigorous peer-review process. To systematize information relative to the editorial process, it is possible to place the contribution of Paidéia in the contemporary scenario of scientific publications in the Humanities field, particularly Psychology.

\section{Editorial Policy and Arbitration Criteria}

With its first publication in 1991, since 2018 Paidéia has adopted the rolling pass system. Paidéia (Ribeirão Preto) is affiliated with the Psychology Graduate Program (Programa de Pós-Graduação em Psicologia) of the Faculdade de Filosofia, Ciências e Letras de Ribeirão Preto at the Universidade de São Paulo (FFCLRP-USP). The Paidéia journal includes research that addresses a problem clearly related to Psychology, specifically in the areas: Psychology of Health, Developmental Psychology, School and Educational Psychology, Social Psychology, and Psychological Evaluation. Paidéia accepts manuscripts 
based on the different theoretical-methodological approaches acknowledged by Psychology. The published articles should fall into the categories: research report, systematic literature review, and theoretical study (submission of these manuscripts is not free and it is limited to authors invited by the Editor).

In 2020, Paidéia completed 29 years of existence. Since its founding in August 1991, 30 volumes have been published, and its collection is fully available through free access provided by the SciELO collection. The volumes are conspicuous for their diversity and breadth of topics and the plurality of methodological designs contained in the articles. The editorial line is generalist, considering the theoreticalmethodological, epistemological, and thematic diversity that permeates the Psychology area.

The Qualis CAPES Periodicals is a procedure used by Coordination for the Improvement of Higher Education Personnel (Coordenação de Aperfeiçoamento de Pessoal de Nivel Superior, CAPES-Brasil) to stratify the quality of intellectual production of Brazilian graduate programs. According to this ranking, Paidéia is classified as A1 level at Qualis CAPES Journals system in the area of Psychology. The highest-ranking evaluation position demonstrates the recognition of the prominent place that the journal occupies within the Brazilian scientific publications.

The prestige given to Paidéia within the scientific community is due to its selective policy of disseminating quality knowledge. A rigorous and thorough assessment is sustained with the support of a highly qualified Editorial Board, structured according to the areas and themes addressed in the articles submitted for consideration. This Council consists of notable names of the academic community, in both the national and international contexts. The processing of the manuscripts is the responsibility of an Editorial Commission composed of Associate Editors. This commission coordinates the rigorous peer review process by utilizing ad hoc consultants with recognized competence, who have the task of evaluating and improving the manuscripts submitted for consideration.

To consolidate its visibility at the national and international level, Paidéia is indexed in a solid set of national and international databases (or full text portals) when compared to the other Brazilian journals in the field of Psychology. Our journal has been indexed in the following databases: SciELO - Scientific Electronic Library Online (FAPESP/BIREME), Scopus (Elsevier), PsycINFO (American PsychologicalAssociation), LILACS-Literatura Latino-Americana e do Caribe em Ciências da Saúde (Centro Latino-americano y de Caribe de Informaciones en Ciencias de la Salud), CLASE - Citas Latinoamericanas en Ciências Sociales y Humanidades (Universidad Nacional Autónoma de México), PSICODOC (Colégio Oficial de Psicólogos de Madrid / Universidad Complutense de Madrid), DOAJ - Directory of Open Access Journals, Ulrich's International Periodicals Directory, Catálogo Latindex, IRESIE (Universidad Nacional Autónoma de México), Index-Psi Periódicos (CFP/PUCCAMP),
Redalyc - Red de Revistas Cientificas de América Latina y el Caribe, España y Portugal, Portal de Revistas da USP (Universidade de São Paulo), ProQuest (CSA) - Databases, EBooks and Technology for Research, EBSCO - Information Services, Cengage Learning, Dialnet (Universidad de La Rioja), OAJI - Open Academic Journals Index, Index Copernicus International (IC Journal Master Listt), HINARI - Access to Research in Health Programme, EZB - Electronic Journals Library (Universität Regensburg Germany), HEAL Link - Hellenic Academic Libraries Link, and Socolar (China Educational Publications Import and Export Corporation - CEPIEC).

The submission of manuscripts is fully computerized through the ScholarOne (Clarivate Analytics) provided by SciELO. The journal adopts a blind review evaluation system, which preserves the anonymity of the authors and reviewers. The texts submitted for consideration must primarily fall within the research report category. In each issue, approximately 39 original research articles are published. As part of the new editorial policy of the journal, the Editorial Board decided to invest heavily in attracting articles that give visibility to research results derived from original empirical studies with quantitative or qualitative designs. The potential to make an impact in the area of knowledge is also a criterion for selecting the manuscripts for publication. To be selected for publication, the manuscripts must be of international interest, rather than just local.

Concerning financing sources, Paidéia has relied on support from financial resources received annually from the Periodical Scientific Publications Support Program of USP (Agência USP de Gestão da Informação Acadêmica AGUIA) and from the Scientific Publications Support Program of the National Council for Scientific and Technological Development (Conselho Nacional de Pesquisa e Desenvolvimento Científico, CNPq-Brasil), as well as the support of the Psychology Graduate Program (Programa de Pós-Graduação em Psicologia) of FFCLRP-USP.

The publication standards are included at the end of each issue, which are available online in Portuguese, English, and Spanish. Those standards (Instructions to the Authors) are available on the SciELO page (http://www.scielo.br/paideia). In addition, the final issue of each volume provides the list of ad hoc evaluators, who contributed to the essential task of reviewing the manuscripts during the year.

Regarding the manuscript arbitration process, Paidéia adopts the mechanism of double-blind review by peers of recognized competence within the scientific community. Thus, the identities of the authors and the ad hoc consultants are kept in strict confidentiality. Nevertheless, the texts submitted for review should be following the guidelines of the publication standards and may be accepted or rejected by the Editorial Board, based on the recommendations of its members and the ad hoc consultants selected to enhance the evaluation process.

In relation to the availability of the content, Paidéia adopts the Creative Commons License, Attribution Non- 
commercial CC BY-NC. With this license, it is permitted to access, download, copy, print, share, reuse, and distribute the articles, provided it is for non-commercial use. Furthermore, it includes the citation of the source, giving appropriate credit to the journal. In such cases, no permission is required from the authors or the publishers.

Another aspect that distinguishes Paidéia in the scenario of Psychology publications is the systematic and periodic provision of information regarding the management process of the journal. In the first issue of each volume/year, we publish a Management Report, in which we seek to provide visibility and transparency to work consolidated in the previous year. This document contains objective indicators to measure the progress of the journal, such as the processing time of the manuscripts, the origin of the authors who have their articles published, and the institutional origins of the reviewers/ad hoc consultants, among other topics of interest (Santos, 2018, 2019; Santos \& Risk, 2020). In addition, in 2017, Paidéia published a special bilingual (Portuguese and English) supplement dedicated to qualitative methodology articles ${ }^{1}$.

Paidéia has also been featured in the SciELO in Perspective: Humanities (blog) where posts on recently published articles are continuously available. For example, in 2020, the following articles were highlighted: (a) Elderly Who Care for Elderly: Double Vulnerability and Quality of Life (Flesch et al., 2020); (b) Coparental Conflict and Triangulation, Emotion Regulation, and Externalizing Problems in Adolescents: Direct and Indirect Relationships (Machado \& Mosmann, 2020); (c) Child Development, Maternal Depression and Associated Factors: A Longitudinal Study (Schiavo \& Perosa, 2020); (d) Educational Social Skills and Repertoire of Children Differentiated by Behavior and Sex (Assis-Fernandes \& Bolsoni-Silva, 2020); (e) Interventions to Reduce Stigma Related to People who Use Drugs: Systematic Review (Tostes et al., 2020).

\section{Editorial Process - 2020}

When considering the editorial process of Paidéia in 2020 , it can be observed that the average processing time of the manuscripts was approximately eight months. In this year, the journal received 90 new manuscripts, of which none were approved, 63 were rejected, and 27 were still in the evaluation process in December of 2020 (Table 1).
Table 1

Editorial Situation of the Manuscripts Submitted to Paidéia in 2020

\begin{tabular}{lc}
\hline Final decision & $n$ \\
\hline Received (Total) & 90 \\
Approved & 0 \\
Rejected & 63 \\
In the editorial process & 27 \\
\hline
\end{tabular}

Note. Mean time between submission and publication in $2020=$ 12 months.

Manuscripts submitted in 2020 were classified in the following categories: (a) Research report $(85.6 \%)$ and (b) Systematic literature review $(14.4 \%)$, as presented in Table 2.

Table 2

Category of the Manuscripts Submitted to Paidéia in 2020

\begin{tabular}{lcc}
\hline Type of manuscript & $n$ & $\%$ \\
\hline Research report & 77 & 85.6 \\
Systematic literature review & 13 & 14.4 \\
Total & 90 & 100.0 \\
\hline
\end{tabular}

As presented in Table 3, in 2020, volume 30, 38 articles and one systematic literature review were published, as well the Management Report. The publications were classified into the following categories: (a) Research report (97.4\%) and (b) Systematic literature review $(2.6 \%)$.

Table 3

Category of the Manuscripts Published in Paidéia in 2020

\begin{tabular}{lcc}
\hline Type of manuscript & $n$ & $\%$ \\
\hline Research report & 38 & 97.4 \\
Systematic literature review & 1 & 2.6 \\
Total & 39 & 100.0 \\
\hline
\end{tabular}

Figure 1 shows the evolution of the number of manuscripts submitted and their fate in the triennium 20182020. These results highlight the rigorous analysis of the manuscripts selected for publication.

\footnotetext{
${ }^{1}$ Available on the link: https://www.scielo.br/scielo.php? script $=$ sci issuetoc\&pid $=0103-863 X 20170004 \& \operatorname{lng}=$ pt\&nrm $=i$ so
} 


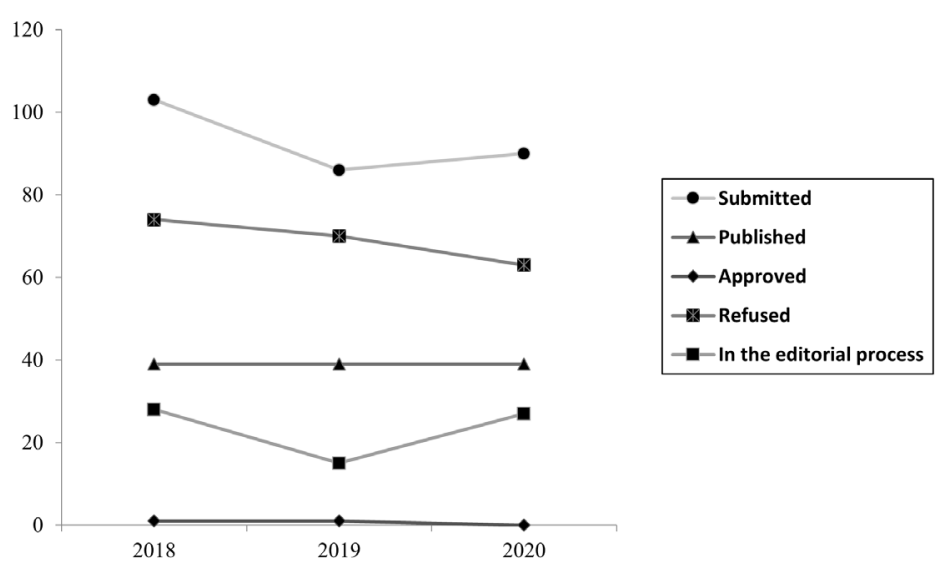

Figure 1. Number of manuscripts submitted to Paidéia and their editorial outcome in the triennium 2018-2020.

Regarding the institutional affiliation of the authors, Table 4 shows that Paidéia published articles originating from 41 Brazilian universities/colleges/institutes. There was a moderate increase in the number of articles with authors affiliated with international institutions, mainly from Portugal,
Colombia, and the United States (Table 5). It should be noted that the authors of the published articles are linked to a variety of higher education institutions, public, private and confessional, of various states of the Brazilian federation and abroad. In 2019, there was a predominance of federal universities over state ones.

Table 4

National Institutional Origin of the Authors who Published in Paidéia in 2020

\begin{tabular}{|c|c|c|}
\hline National institutions & $n$ & $\%$ \\
\hline Universidade São Francisco-SP & 13 & 11.7 \\
\hline Universidade de São Paulo-SP & 12 & 10.8 \\
\hline Universidade Federal da Bahia-BA & 10 & 9.0 \\
\hline Universidade Federal do Rio Grande do Sul-RS & 7 & 6.3 \\
\hline Universidade Federal de Juiz de Fora-MG & 6 & 5.4 \\
\hline Universidade Estadual de Montes Claros-MG & 5 & 4.5 \\
\hline Universidade de Brasília-DF & 4 & 3.6 \\
\hline Universidade Estadual Paulista Júlio de Mesquita Filho-SP & 4 & 3.6 \\
\hline Universidade Federal de São Carlos-SP & 4 & 3.6 \\
\hline Pontifícia Universidade Católica do Rio Grande do Sul-RS & 3 & 2.7 \\
\hline Universidade do Estado de Santa Catarina-SC & 3 & 2.7 \\
\hline Universidade Estadual de Campinas-SP & 3 & 2.7 \\
\hline Universidade Federal do Ceará-CE & 2 & 1.8 \\
\hline IMED-RS & 2 & 1.8 \\
\hline Pontifícia Universidade Católica de Goiás-GO & 2 & 1.8 \\
\hline Universidade de Fortaleza-CE & 2 & 1.8 \\
\hline Universidade do Vale do Rio dos Sinos-RS & 2 & 1.8 \\
\hline Universidade Federal de São Paulo-SP & 2 & 1.8 \\
\hline Universidade Federal do Espírito Santo-ES & 2 & 1.8 \\
\hline Universidade Presbiteriana Mackenzie-SP & 2 & 1.8 \\
\hline Centro Universitário das Faculdades Associadas de Ensino-SP & 1 & 0.9 \\
\hline Centro Universitário UniAcademia-MG & 1 & 0.9 \\
\hline Faculdade Especializada na Área da Saúde do Rio Grande do Sul-RS & 1 & 0.9 \\
\hline Faculdade Meridional-RS & 1 & 0.9 \\
\hline Fundação de Assistência Social e Cidadania-RS & 1 & 0.9 \\
\hline Fundação Getulio Vargas-SP & 1 & 0.9 \\
\hline Pontifícia Universidade Católica de São Paulo-SP & 1 & 0.9 \\
\hline Tribunal de Justiça de Minas Gerais-MG & 1 & 0.9 \\
\hline Universidade Tuiuti do Paraná-PR & 1 & 0.9 \\
\hline Universidade Católica de Petropólis-RJ & 1 & 0.9 \\
\hline Universidade de Franca-SP & 1 & 0.9 \\
\hline Universidade de Viçosa-MG & 1 & 0.9 \\
\hline Universidade Federal de Minas Gerais-MG & 1 & 0.9 \\
\hline Universidade Federal de Pelotas-RS & 1 & 0.9 \\
\hline Universidade La Salle-RS & 1 & 0.9 \\
\hline Universidade Salgado de Oliveira-RJ & 1 & 0.9 \\
\hline Universidade Estadual de Londrina-PR & 1 & 0.9 \\
\hline Universidade Federal de Roraima-RR & 1 & 0.9 \\
\hline Universidade Federal de São Paulo-SP & 1 & 0.9 \\
\hline Universidade Federal do Pará-PA & 1 & 0.9 \\
\hline Universidade Federal do Rio Grande-RS & 1 & 0.9 \\
\hline Total & 111 & 100.0 \\
\hline
\end{tabular}


Table 5

International Institutional Origin of the Authors who Published in Paidéia in 2020

\begin{tabular}{lcc}
\hline International institutions & $n$ & $\%$ \\
\hline Pontificia Universidad Javeriana, Cali, Colombia & 4 & 21.1 \\
Universidade de Lisboa, Lisboa, Portugal & 3 & 15.8 \\
Universidade do Minho, Braga, Portugal & 3 & 15.8 \\
Universidade Portucalense Infante D. Henrique (UPT), Portugal & 2 & 10.5 \\
Auburn University, Alabama, USA & 5.3 \\
Deakin University, Australia & 1 \\
Institute of Higher Studies in Fafe (IESF), Portugal & 1 \\
Pontificia Universidad Javeriana, Bogotá, Colombia & 1 \\
Universidade Católica Portuguesa, Lisboa, Portugal & 5.3 \\
University of Adelaide, Adelaide-SA, Australia & 5.3 \\
University of Richmond, Virginia, USA & 1 \\
Total & 5.3 \\
\hline
\end{tabular}

\section{Final Considerations}

In recent years, Paidéia has worked hard to consolidate itself as one of the most prestigious Psychology publications in the Brazilian context. With a true entrepreneurial spirit, coordinated actions have been implemented to create objective conditions for the internationalization of the journal, which enhanced the visibility of the articles published.

This management report systematizes information that permits the mapping of the framework of the editorial processing of the manuscripts submitted to the Paidéia during the year 2020. Comparison of the data accumulated over the last three years shows that the journal has gradually and consistently strengthened its editorial process, establishing itself as a unifying space for the knowledge produced in the field of Psychology. However, some fragilities need to be considered, such as the limited number of international collaborations and the concentration of ad hoc consultants in the Southeastern states. The low percentage of articles from foreign authors is a limitation as well. Overcoming these challenges requires the adoption of specific strategies.

One positive aspect to be highlighted in this report is the adoption of the full text of the articles in English in 2012, which gives greater international visibility to the articles published in the journal. In addition, the journal has ensured its inclusion in new global indexes, which contributes to the internationalization efforts.

Since 2018 Paidéia has adopted the rolling pass system. Another positive point is that the journal's rate of "endogeneity" (articles from authors of the Universidade de São Paulo $-10.8 \%$ of the articles published in 2020 - had a slight decrease considering the last year of the historical series. This rate was $11.5 \%$ in 2019 (Santos \& Risk, 2020); 7.1\% in 2018 (Santos, 2019); 10.4\% in 2017 (Santos, 2018). In other words, Paidéia proves to be a journal that is truly open to the Brazilian scientific community and, in recent years, increasingly oriented towards the international community.

Regarding science communication, it must be remembered that the publication may be through various means, with scientific journals highlighted due to quality control, greater credibility, consistency, and visibility of information. Scientific knowledge is mainly derived from original research, submitted to the peer-review process, and published in an indexed journal, with attention to the use and impact of the information conveyed. Being indexed in specialized or multidisciplinary databases is the seal of the quality of a journal.

Considering the significant increase in the national scientific production in recent years, due to a stimulus policy that is unfortunately often confused with the deleterious productivism resulting from the pressure to publish, national journals should give greater transparency to their publishing processes. Thus, this Management Report complies with the social mission of returning to society the result of public investments that have been allocated in recent years to the field of science and technology. Finally, scientific journals play an important role in evaluating the quality and dissemination of the knowledge produced in the area of Psychology. They are the principal means of publication and also the most prestigious and credible.

\section{References}

Assis-Fernandes, R. P., \& Bolsoni-Silva, A. T. (2020). Educational social skills and repertoire of children differentiated by behavior and sex. Paidéia (Ribeirão Preto), 30, e3015. doi:10.1590/1982-4327e3015

Carvalho, L. F., Pianowski, G., \& Santos, M. A. (2019). Guidelines for conducting and publishing systematic reviews in Psychology. Estudos de Psicologia (Campinas), 36, e180144. doi:10.1590/1982-0275201936e180144

Ferreira, H. G. (2021). Gender differences in mental health and beliefs about Covid-19 among elderly internet users. Paidéia (Ribeirão Preto), 31, e3110. doi:10.1590/1982-4327e3110

Flesch, L. D. et al. (2020). Elderly who care for elderly: Double vulnerability and quality of life. Paidéia (Ribeirão Preto), 30, e3003. doi:10.1590/1982-4327e3003 
Machado, M. R., \& Mosmann, C. P. (2020). Coparental conflict and triangulation, emotion regulation, and externalizing problems in adolescents: Direct and indirect relationships. Paidéia (Ribeirão Preto), 30, e3004. doi:10.1590/1982-4327e3004

Oliveira, W. A., Oliveira-Cardoso, E. A., Silva, J. L., \& Santos, M. A. (2020). Impactos psicológicos e ocupacionais das sucessivas ondas recentes de pandemias em profissionais da saúde: Revisão integrativa e lições aprendidas. Estudos de Psicologia (Campinas), 37, e200066. doi:10.1590/1982-0275202037e200066

Oliveira, W. A., Silva, J. L., Andrade, A. L. M., Micheli, D., Fernández, J. E. R., Dellazzana-Zanon, L. L., Silva, M. A. I., \& Santos, M. A. (2020a). Adolescence in times of pandemic: Integrating consensus into a concept map. Estudos de Psicologia (Natal), 25(2), 133143. doi:10.22491/1678-4669.20200014

Oliveira, W., Magrin, J., Andrade, A., Micheli, D., Carlos, D., Fernandez, J., Silva, M., \& Santos, M. (2020b). Violência por parceiro íntimo em tempos da COVID-19: Scoping review. Psicologia, Saúde \& Doenças, 21(3), 606-623. doi:10.15309/20psd210306

Oliveira, W. A., Andrade, A. L. M., Souza, V. L. T., De Micheli, D., Fonseca, L. M. M., Andrade, L. S., Silva, M. A. I., \& Santos, M. A. (2021). COVID-19 pandemic implications for education and reflections for school psychology. Psicologia: Teoria e Prática, 23(1), 1-26. doi:10.5935/1980-6906/ePTPC1913926

Oliveira-Cardoso, E. A., Silva, B. C. A., Santos, J. H., Lotério, L. S., Accoroni, A. G., \& Santos, M. A. (2020). The effect of suppressing funeral rituals during the COVID-19 pandemic on bereaved families. Revista Latino-Americana de Enfermagem, 28, e3361. doi:10.1590/1518-8345.4519.3361

Psychology Graduate Program - Programa de PósGraduação em Psicologia USP-RP (2021, August 19). Evento comemorativo dos 30 anos - Paidéia (Ribeirão Preto) [Video]. YouTube. https://www.youtube.com/ watch? $\mathrm{v}=\mathrm{Ig} 32 \mathrm{Nrcy} J 8 \mathrm{Q}$

Risk, E. N. (2010). A editoração científica em questão: Dimensões da Psicologia. Revista Brasileira de Orientação Profissional, 11(1), 151-153. Retrieved from http://pepsic.bvsalud.org/scielo.php?script=sci arttext\&pid=S1679-33902010000100015

Santos, M. A. (2018). Paidéia: Management report - 2017. Paidéia (Ribeirão Preto), 28, e2801. doi:10.1590/1982$4327 \mathrm{e} 2801$

Santos, M. A. (2019). Paidéia: Management report - 2018. Paidéia (Ribeirão Preto), 29, e2940. doi:10.1590/1982$4327 \mathrm{e} 2940$

Santos, M. A., Oliveira, W. A., \& Oliveira-Cardoso, E. A. (2020). Inconfidências de abril: Impacto do isolamento social na comunidade trans em tempos de pandemia de COVID-19. Psicologia \& Sociedade, 32, e020018. doi:10.1590/1807-0310/2020v32240339
Santos, M. A., \& Risk, E. N. (2020). Paidéia: Management report - 2019. Paidéia (Ribeirão Preto), 30, e3001. doi:10.1590/1982-4327e3001

Schiavo, R. A., \& Perosa, G. B. (2020). Child development, maternal depression and associated factors: A longitudinal study. Paidéia (Ribeirão Preto), 30, e3012. doi:10.1590/1982-4327e3012

Tostes, J. G. A. et al. (2020). Interventions to reduce stigma related to people who use drugs: Systematic review. Paidéia (Ribeirão Preto), 30, e3022. doi: 10.1590/1982-4327e3022

Manoel Antônio dos Santos is an Full Professor of the Faculdade de Filosofia, Ciências e Letras de Ribeirão Preto at the Universidade de São Paulo, Ribeirão Preto-SP, Brasil and Editor In-Chief of Paidéia (Ribeirão Preto).

Eduardo Name Risk is an Assistant Professor of Departamento de Psicologia from Centro de Educação e Ciências Humanas at the Universidade Federal de São Carlos, São Carlos-SP, Brasil, and Assistant Editor of Paidéia (Ribeirão Preto).

How to cite:

Santos, M. A., \& Risk, E. N. (2021). The year that is not yet over - Paidéia: Management Report 2020. Paidéia (Ribeirão Preto), 31, e3101. doi:https://doi.org/10.1590/1982-4327e3101 